Original Article

\title{
Anatomical and histological traits of Brycon amazonicus liver cultivated in a semi-intensive system
}

\author{
Características anatômicas e histológicas do fígado de Brycon amazonicus cultivado em \\ sistema semi-intensivo
}

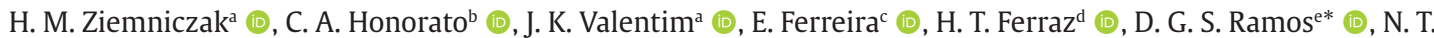 \\ Vieira $^{\mathrm{f}}$ (D) and K. C. Saturnino ${ }^{\mathrm{e}}$ (D) \\ aniversidade Federal da Grande Dourados - UFGD, Faculdade de Ciências Agrárias, Dourados, MS, Brasil \\ bUniversidade Federal da Grande Dourados - UFGD, Faculdade de Ciências Agrárias, Programa de Pós-graduação em Zootecnia, Dourados, MS, Brasil \\ 'Universidade Federal de Rondônia - UNIR, Programa de Pós-graduação em Ciências Ambientais, Rolim de Moura, RO, Brasil \\ dUniversidade Federal de Jataí - UFJ, Unidade Acadêmica Especial de Ciências Agrárias, Jataí, GO, Brasil \\ eUniversidade Federal de Jataí - UFJ, Programa de Pós-graduação em Biociência Animal, Unidade Acadêmica de Ciências Agrárias, Jataí, GO, Brasil \\ fSanta Casa BH, Departamento de Ortopedia, Belo Horizonte, MG, Brasil
}

\begin{abstract}
The work aimed to evaluate the weight-length relationship and the condition factor, characterizing the biometry, anatomy, histology and volumetric density of the liver of Brycon amazonicus, in different stages of body growth. The experiment used twenty specimens in four stages of body growth (PI, PII, PIII and PIV) harvested every 90 days, containing five specimens, each group. The livers were dissected, weighed ( $\mathrm{g}$ ) and processed routinely using the hematoxylin and eosin technique. The data were submitted to analysis of variance, Pearson's correlation test and linear regression. The equation that represented the weight-length relation was $\mathrm{W}=0.05902 \times \mathrm{LL}^{2.63}$, with negative allometric growth, but with a relative condition factor equal to 1.0. The liver was divided into three lobes with the gallbladder close to the right lobe and its color varied from light red to dark red, not varying in relation to other fish species. The hepatosomatic relationship followed body growth until the PII group stage and then declined, demonstrating the behavior of its development in Brycon amazonicus. The organ consists predominantly of hepatocytes, followed by sinusoidal vessels and capillaries, with histological morphology similar to that of many species of fish. Melanomacrophage centers were found only in the most developed animals, but in small quantities, prompting the development of new research on this cell, in this species. In this way, research of this nature allows the characterization of fish species, helping to improve breeding methods, understanding pathological processes caused by diseases, and obtaining better productive capacity, serving an increasingly demanding and prosperous market.
\end{abstract}

Keywords: biometrics, hepatic data, histomorphometry, Matrinxã.

\begin{abstract}
Resumo
O trabalho objetivou avaliar a relação peso-comprimento e o fator de condição, caracterizando a biometria, anatomia, histologia e densidade volumétrica do fígado de Brycon amazonicus, em diferentes estágios de crescimento corporal. O experimento utilizou vinte espécimes em quatro fases de crescimento corporal (PI, PII, PIII e PIV) colhidos a cada 90 dias, contendo cinco espécimes, cada grupo. Os fígados foram dissecados, pesados ( $\mathrm{g}$ ) e processados rotineiramente pela técnica da hematoxilina e eosina. Os dados foram submetidos à análise de variância, teste de correlação de Pearson e regressão linear. A equação que representou a relação peso-comprimento foi $W=0,05902 \times \mathrm{L}^{2,63}$, com crescimento alométrico negativo, mas com fator de condição relativo igual a 1,0. O fígado apresentou-se dividido em três lobos com a vesícula biliar próxima ao lobo direito e sua cor variou de vermelho claro a vermelho escuro, não variando em relação a outras espécies de peixes. A relação hepatossomática acompanhou o crescimento corporal até a fase do grupo PII e então declinou, demonstrando o comportamento de seu desenvolvimento em Brycon amazonicus. $\mathrm{O}$ órgão constitui-se predominantemente por hepatócitos, seguido de vasos e capilares sinusoidais, com a morfologia histológica semelhante ao de muitas espécies de peixes. Centros melanomacrófagos foram encontrados apenas nos animais mais desenvolvidos, mas em pequena quantidade, instigando o desenvolvimento de novas pesquisas sobre esta célula, nesta espécie. Desta forma, pesquisas desta natureza permitem a caracterização de espécies de peixes, auxiliando no aperfeiçoamento de métodos de criação, compreensão de processos patológicos provocados por enfermidades, e obtenção de melhor capacidade produtiva, atendendo um mercado cada vez mais exigente e próspero.
\end{abstract}

Palavras-chave: biometria, dados hepáticos, histomorfometria, Matrinxã.

*e-mail: dgramos_vet@hotmail.com

Received: October 20, 2020 - Accepted: March 23, 2021 


\section{Introduction}

World aquaculture grows at a rate of $5.8 \%$ per year as result of a series of combined factors, such as growth in the human population and increased urbanization, thus requiring high quality consumer products. Worldwide, fish contribute about $18 \%$ of the total animal protein consumed by man (FAO, 2017), making it a great option as an animal protein source. Global fish production reached about 179 million tons, generating an estimated value of US\$ 401 billion, 82 million of which, valued at US\$ 250 billion from aquaculture (FAO, 2020). Brazil produced $1,348,315,000$ fries of fish in 2019 (IBGE, 2020), with a $5 \%$ increase in production from the previous year.

In this context, Brycon amazonicus Spix \& Martius, 1829 is one of the most produced species in Brazil. Popularly known as "matrinxã", belongs to the class Actinopterygii, order Characiformes, family Bryconidae and genus Brycon (Santos et al., 2006). Its production reaches the second place in the Amazon region, due to its cultivation characteristics, such as omnivorous eating habits and good acceptance of rations with the inclusion of by-products (Honczaryk and Inoue, 2009). Its growth rate is high, in addition to having high commercial interest due to its good acceptance in the consumer market, rapid growth, easy handling of food from its early stages of reproduction and great potential for semi-intensive rearing (Barros et al., 2019).

The liver plays an essential role in metabolism, which includes digestion, excretion, protein synthesis, endocrine function and energy storage (Genten et al., 2009; Faught and Vijayan, 2016), in addition to being the main organ related to detoxification (Mahfouz and Sherif, 2015; Bedoya-Serna et al., 2018; Anater et al., 2020).

The constant generation of information about species cultivated for commercialization, especially those of great economic importance, is essential for improving productivity. In this context, studies on B. amazonicus, would serve as a basis for the management and conservation of the species. A study tool that has been growing in ichthyology is the weight-length ratio and the histology of many different tissues. The weight-length equation can provide information on the relative growth of a given species, in other words, it evaluates its allometric growth (Navarro et al., 2006). In this context, Rego et al. (2008) suggest that allometry studies should be used to characterize the different fish growth strategies associated with the ecological, behavioral and physiological factors of the species. It has been used in several studies to elucidate possible cell lesions or to describe the normal appearance of tissues under different aspects (Morrison, 2007; Genten et al., 2009; Rodrigues et al., 2017; Anater et al., 2020). In addition, when associated with histomorphometry, they can be used in the evaluation of normal and comparative parameters in studies on nutrition, growth, intoxication and damage caused by diseases (Ferguson, 1989), contributing to their productivity.

In this context, the present study aims to evaluate the weight-length relationship and the condition factor, characterizing the biometry, anatomy, histology and volumetric density of the liver of an important fish in the Amazon biome, B. amazonicus, cultivated semi-intensively, in four different stages of body growth.

\section{Material e Methods}

To carry out the experiment, four experimental groups were acquired, containing five corpses each. The animals were collected from the same place, randomly, every 90 days, measured $(\mathrm{cm})$, weighed $(\mathrm{g})$ and necropsied according to Fisher and Myers (2000), resulting in: PI $(\mathrm{n}=5 ; \mathrm{TL}=24.60 \pm 0.39 \mathrm{~cm} ; \mathrm{W}=278.40 \pm 33.18 \mathrm{~g})$, PII ( $\mathrm{n}=5 ; \mathrm{TL}=36.90 \pm 0.39 \mathrm{~cm} ; \mathrm{W}=745.40 \pm 33.18 \mathrm{~g})$, PIII $(\mathrm{n}=5 ; \mathrm{TL}=43.00 \pm 0.39 \mathrm{~cm} ; \mathrm{W}=1,153.40 \pm 33.18 \mathrm{~g})$ and $\operatorname{PIV}(\mathrm{n}=5 ; \mathrm{TL}=47.00 \pm 0.39 \mathrm{~cm} ; \mathrm{W}=1,591.80 \pm 33.18 \mathrm{~g})$.

The animals were grown in excavated tanks, with food handling of commercial feed containing $28 \%$ crude protein (CP), once a day. PI and PII received feed equivalent to $2 \%$ of biomass, while PIII and PIV received $1.2 \%$, according to the manufacturer's recommendation (Nutrizon ${ }^{\circledR}$ ) (Ushizima et al., 2016).

For the analysis of the weight-length relationship, the data for each animal (length and total weight) were adjusted by the equation $\mathrm{W}=\mathrm{a} \cdot \mathrm{L}^{\mathrm{b}}$, where $\mathrm{W}$ is the weight of each individual, $\mathrm{L}$ is the total length, $a$ the condition factor or intercept and $b$ the angular or allometric coefficient. The adjusted determination coefficient $\left(R^{2}\right)$ was also determined in order to assess how much the variability in weight (dependent variable) is explained by the variability in length (independent variable). Weight and length underwent logarithmic transformation to calculate $a$ and $b$, through linear regression analysis $(\mathrm{P}<0.05)$. Weight growth was assessed by the degree of allometry in negative $(b<3)$, isometric $(b=3)$ or positive (b $>3)$. To calculate the condition factor, the relative condition factor $(\mathrm{Kn})$ was used, resulting from the equation $\mathrm{Kn}=$ observed weight / expected weight, where the observed weight was informed by the property and the expected weight, the weight found by the equation of the relation weight-length (Le Cren, 1951).

For hepatic biometrical analysis, each liver was dissected through the section of the celomatic artery, vena cava and portal vein next to the organ. Then, the gallbladder was dissected and removed at the origin of the bile duct (Fisher and Myers, 2000), at visceral face of the organ. It was weighed individually to obtain the hepatosomatic relationship using the formula: HSR = (liver weight / total weight) x 100 (Tavares-Dias et al., 2000). For histological analysis, liver fragments were fixed in $4 \%$ buffered formaldehyde for $48 \mathrm{~h}$, processed by routine histological techniques and included in paraffin, cut to $5 \mu \mathrm{m}$ and stained by hematoxylin and eosin (HE) techniques.

For the analysis of the volumetric density, 20 random images (1024 x 760 pixels) of each sample were captured, with the aid of a photographic camera for light field microscopy (Nikkon Eclipse E200) coupled in an ocular lens (Coslab, MDCE-5C ${ }^{\circledR}$ ) in the magnitude of $200 \mathrm{x}$.

Each image was divided into gradients adjusted to 2550 pixels $^{2}$, totaling 342 intersections, which corresponded to the points used for classical manual stereological technique, based on the point count (Sundberg, 1992). In each image of the liver, the following structural densities were calculated, by percentage (\%): hepatocytes, sinusoidal spaces, blood vessels, connective 
tissue, melanomacrophage centers (MMC's) and pancreatic tissue, in case of occurrence. The percentage of each structure was calculated for each image using the following formula: structure $(\%)=($ total count $/ 342) \mathrm{x}$ 100 . The software Image J $1.46^{\circledR}$ was used.

The data of the volumetric density of the livers were checked for normality and homogeneity of the variances, and then compared between the samples through the analysis of variance (ANOVA), univariate model (Tukey's test, $\mathrm{P}<0.05)$. The data on the hepatosomatic relationship and total length were correlated using the Pearson test $(\mathrm{P}$ $<0.05)$. The weight-length ratio equation was established by linear regression analysis $(\mathrm{P}<0.05)$, with an adjusted determination coefficient.

All procedures were approved by the Animal Use Ethics Committee of Federal University of Jatai (CEUA/ REJ/UFG - 003/2019), which is registered with COBEA (Brazilian College of Animal Experimentation).

\section{Results}

The equation that represented the weight-length relationship was $\mathrm{W}=0.05902 \times \mathrm{L}^{2.63}$, and its behavior represented by Figure 1 . Thus, the value of the allometric coefficient was $b=2.63(\mathrm{P}<0.01)$, in other words, negative allometric growth. The adjusted determination coefficient was $\mathrm{R}^{2}=0.99$ and the average relative condition factor was $\mathrm{Kn}=1.0$.

Macroscopically, the liver presented a light red (PI) to a brownish red-brown color (other groups) and always divided into right, middle and left lobes (see
Figure 2). In the right hepatic lobe, the gallbladder was observed, while the middle hepatic lobe was located cranio-ventrally in the celomatic cavity, anterior to the stomach and ventrally to the esophagus. The left hepatic lobe was located close to the spleen. The analysis of the hepatosomatic relationship in the evaluated specimens is shown in Figure 3. The means of the hepatosomatic relationship involving all groups was $1.71 \pm 0.44$. The correlation analysis between the total length and the hepatosomatic relationship was $r=-0.469(P<0.05)$, with $\mathrm{R}^{2}=0.22$, demonstrating that the correlation between the hepatosomatic relationship and the total length are reversed and weak.

Histologically, the hepatic parenchyma consisted of hepatocytes arranged in linear cords, with large, rounded nuclei, located in the central or basal region of the cell; prominent nucleolus and with sinusoidal vessels present between hepatocytes.

The pancreas was observed attached to the liver parenchyma, commonly found around blood vessels, as an outer layer of cells around some hepatic portal veins. In addition, it had a thin layer of connective tissue separating pancreatic cells from the liver parenchyma. (see Figure 4).

Melanomacrophage centers (MMC's) were observed only in the liver of category PIV in this species. Table 1 shows the mean values with respective standard deviations, confidence intervals (IC 95\%) and the differences found in terms of volumetric density between the four categories evaluated.

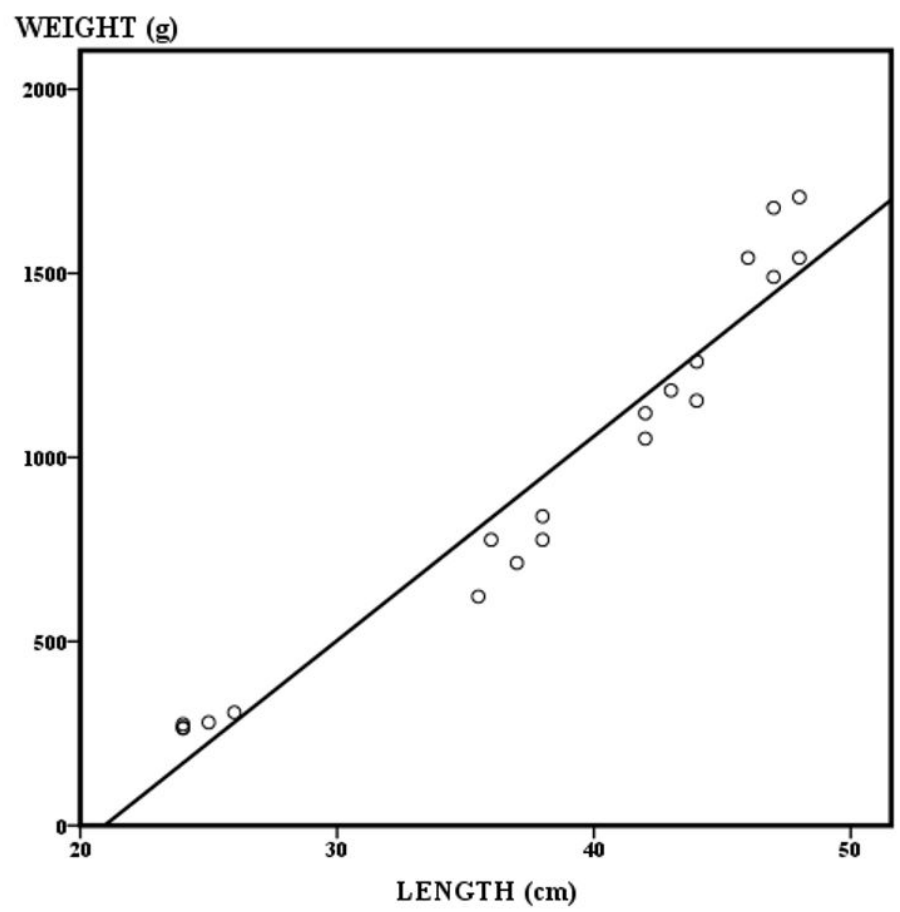

Figure 1. Graphical representation resulting from the analysis of the weight-length ratio of B. amazonicus cultivated semi-intensively, in four stages of body growth. 

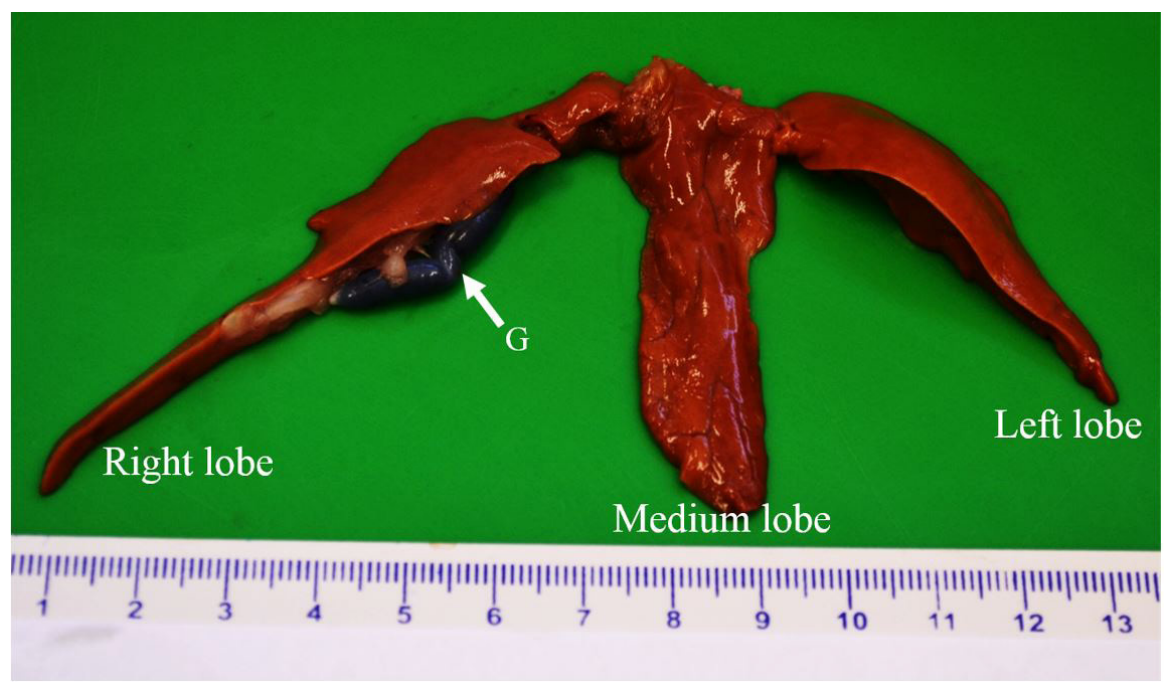

Figure 2. Brycon amazonicus liver after removal of the celomatic cavity and dissection of an individual belonging to the PIII. Note the hepatic lobation and gallbladder $(G)$ located next to the right hepatic lobe, and the red-brown color of de liver.

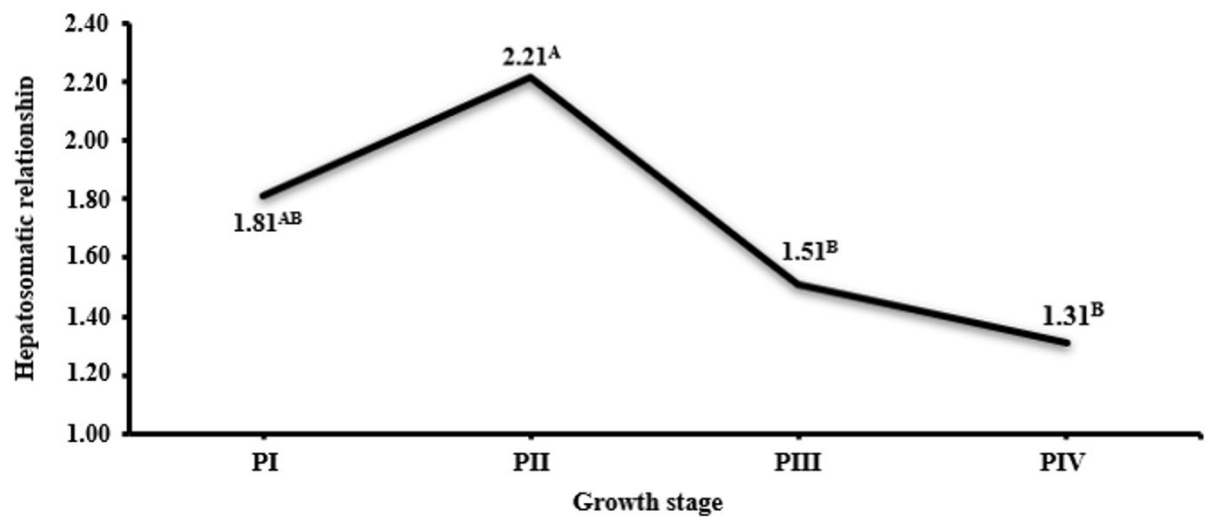

Figure 3. Behavior of semi-intensively cultivated Brycon amazonicus hepatosomatic relationship, according to body growth. Different letters represent significant differences between groups $(\mathrm{P}<0.05)$.

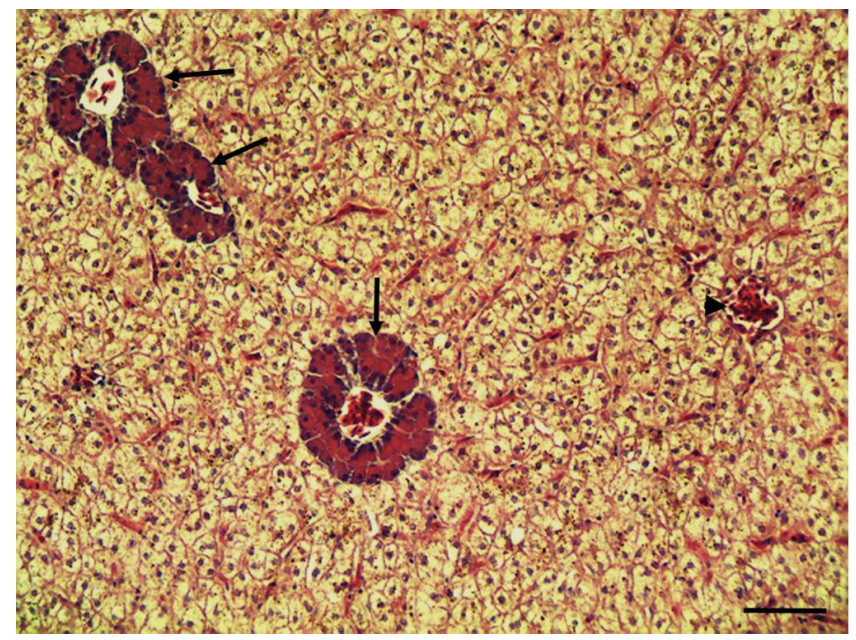

Figure 4. Microscopic image of Brycon amazonicus liver from semi-intensive cultivation. Note the cordonal aspect of the hepatocytes, the absence of lobulation and the presence of blood vessels without pancreatic tissue wrap (arrowhead) and with pancreatic cells surrounding them (arrow). HE, 200X. Bar $=50 \mu \mathrm{m}$. 
Table 1. Means, standard deviation $( \pm$ ) and confidence interval $(95 \%)$ of the volumetric density of the liver of Brycon amazonicus ( $\mathrm{n}=$ 20) according to body growth, produced in semi-intensive fish farming.

\begin{tabular}{|c|c|c|c|c|c|c|c|}
\hline $\mathbf{P}$ & Hepatoc. & Sinus. & Vessels & Panc. & Conect. & Duct & CMM \\
\hline \multirow[t]{2}{*}{ PI } & $92.06 \pm 1.10^{\mathrm{B}}$ & $3.21 \pm 0.41^{\mathrm{AB}}$ & $4.14 \pm 0.47^{\mathrm{BC}}$ & $0.51 \pm 0.73^{\mathrm{A}}$ & $0.02 \pm 0.33^{\mathrm{A}}$ & $0.05 \pm 0.02^{\mathrm{AB}}$ & $0.00 \pm 0.00^{\mathrm{A}}$ \\
\hline & $\begin{array}{c}(90.06- \\
94.07)\end{array}$ & $(2.40-4.02)$ & $(3.22-5.07)$ & $(0.90-1.95)$ & $(0.05-0.08)$ & $(0.01-0.08)$ & $(0.00-0.00)$ \\
\hline \multirow[t]{2}{*}{ PII } & $85.20 \pm 1.11^{\mathrm{A}}$ & $8.98 \pm 0.41^{\mathrm{c}}$ & $1.44 \pm 0.47^{\mathrm{A}}$ & $4.34 \pm 0.73^{\text {в }}$ & $0.03 \pm 0.34^{\mathrm{A}}$ & $0.00 \pm 0.02^{\mathrm{A}}$ & $0.00 \pm 0.00^{\mathrm{A}}$ \\
\hline & $(83.17-87.22)$ & $(8.16-9.80)$ & $(0.51-2.38)$ & (2.89-5.79) & $(0.03-0.10)$ & $(0.00-0.38)$ & $(0.00-0.00)$ \\
\hline \multirow[t]{2}{*}{ PIII } & $85.67 \pm 1.09^{\mathrm{A}}$ & $2.84 \pm 0.41^{\mathrm{A}}$ & $3.90 \pm 0.72^{\mathrm{B}}$ & $7.50 \pm 0.72^{\mathrm{c}}$ & $0.05 \pm 0.33^{A}$ & $0.03 \pm 0.02^{\mathrm{AB}}$ & $0.00 \pm 0.00^{A}$ \\
\hline & $\begin{array}{l}(83.67- \\
87.66)\end{array}$ & $(2.03-3.64)$ & $(2.97-4.82)$ & $(6.08-8.93)$ & $(0.01-0.12)$ & $(0.00-0.07)$ & $(0.00-0.00)$ \\
\hline \multirow[t]{2}{*}{ PIV } & $83.07 \pm 1.08^{A}$ & $4.28 \pm 0.38^{\mathrm{B}}$ & $6.18 \pm 0.60^{c}$ & $5.96 \pm 0.77^{\mathrm{BC}}$ & $0.18 \pm 0.04^{\mathrm{A}}$ & $0.16 \pm 0.03^{\mathrm{B}}$ & $0.15 \pm 0.03^{\mathrm{B}}$ \\
\hline & $\begin{array}{c}(80.85- \\
85.20)\end{array}$ & $(3.53-5.03)$ & $(4.99-7.37)$ & $(4.44-7.48)$ & $(0.09-0.28)$ & $(0.09-0.23)$ & $(0.09-0.21)$ \\
\hline
\end{tabular}

P: Growth stage, Hepatoc: hepatocytes, Sinus: sinusoid, Panc: pancreatic tissue, Conect: conective tissue, MMC: melanomacrophage centers. A,B,CDifferent letters between columns represent a significant difference between groups $(P<0,05)$.

In all groups evaluated, the percentage of hepatocytes was predominant. When compared, the PI group obtained a higher percentage of hepatocytes, compared to the other groups. Regarding the percentage of pancreatic tissue, it varied between the four categories evaluated, increasing the proportion according to body weight. Regarding the vessels and sinusoid, the proportional inversion between these structures in the PII category stands out.

In contrast, there is no variation in the percentage of connective tissue between the groups, which accompanies the growth of this viscera, demonstrating the developmental balance between the other structures. As for the bile ducts, it was observed that this structure is present in low concentration in the liver of this species.

\section{Discussion}

The weight-length relationship, which uses the equation $\mathrm{W}=\mathrm{a} \cdot \mathrm{L}^{\mathrm{b}}$, is very important for carrying out studies on the life cycle of farm and wildlife fish and can be used for morphometric comparisons between populations. In addition, its analysis makes it possible to provide the growth coefficient of the species under study, in addition to the condition factor (Le Cren, 1951). In the present study, the observed allometric growth was negative, that is, the increase in weight was more pronounced than in length (Flynn et al., 2011), and the model explained 99\% of the weight variance in relation to the total length. Le Cren (1951) states that the values of this coefficient can vary between 2.5 and 4 , but are generally around 3, considered isometric growth, or ideal.

The condition factor is an index widely used in ichthyology because it provides information on the degree of well-being of the fish in the environment in which they live (Braga, 1986; Flynn et al., 2011). This factor reflects recent nutritional aspects and/or reserve expenditures in cyclical activities, demonstrating that the cultivation of the animals in the study was considered adequate and favorable to their development, without negative interference from the environment.
Bruslé and Anadon (1996) describe that most teleosts have two hepatic lobes, Takashima and Hibiya (1995) describe species with 3 wolves, such as Colossoma macropomum Cuvier, 1816 (Costa et al., 2012) and Leporinus macrocephalus Garavello \& Britski, 1988 (Bombonato et al., 2007) Saturnino (2016) and Rodrigues et al. (2017) described the anatomy of Arapaima gigas Schinz, 1822 and the surubim hybrid (Pseudoplatystoma reticulatum Eigenmann \& Eigenmann, 1889 x Pseudoplatystoma corruscans Spix \& Agassiz, 1829), respectively. Both studies pointed to the existence of a single wolf for both species. Thus, like the results in Brycon amazonicus, it is evident that the liver can vary in shape and size among teleost fish species (Bruslé and Anadon, 1996; Tavares-Dias et al., 2000; Costa et al., 2012).

Variables such as age, physiological condition of the fish and the environment itself, can contribute to the occurrence of variations in the size of the liver of these animals (Tavares-Dias et al., 2000), and influence the hepatosomatic relationship, corroborating with the present study, where the variation was due to the different phases of growth and energy reserve, evidenced by the difference in color between PI and the others (Gomiero and Braga, 2003).

It is observed that in the PI and PII groups, the liver increased in size along with body growth, but later it did not follow this trend. The correlation analysis between the variables liver weight and body weight resulted in $r=-0.469$, proving what the graph shows, that is, although the liver develops together with the body, its growth stabilizes after a certain phase, maintaining its function and metabolic capacity. In addition, the determination coefficient was low $\left(R^{2}=0.22\right)$, implying that body development has a low influence on liver growth. In this context, it is highlighted that the liver is an important metabolizing and energy reserve organ, especially in fish, storing fat and glycogen (Gomiero and Braga, 2003), and in this species, it reaches its balance after a certain growth phase, between PII and PIII.

The decrease in feed rates in relation to biomass was lower for groups PIII and PIV, justifying, therefore, their lower hepatosomatic relationship. Such information about 
the influence of the number of stored reserves, influencing the size of hepatocytes and liver volume, could be proven through the morphometry of these cells as demonstrated in Arapaima gigas Schinz, 1822 (Saturnino, 2016).

In addition, the results found in $B$. amazonicus demonstrate that its HSR average $(1.71 \pm 0.44)$ was similar or superior to those reported in Oreochromis niloticus Linnaeus, 1758 (1.44 \pm 0.28$)$, L. macrocephalus (1.07 \pm 0.25 ), tambacu hydrid (Piaractus mesopotamicus Holmberg, $1887 \mathrm{x}$ C. macropomum $)(1.09 \pm 0.22)$ and P. mesopotamicus $(1.05 \pm$ 0.14) (Tavares-Dias et al., 2000). Benacon et al. (2015) evaluated 40 specimens of wild $B$. amazonicus. In their study, an HSR of $1.42 \pm 0.27$ was observed, a value similar to that found in the present study. Tavares-Dias et al. (2018) also obtained similar values for B. amazonicus (HSR $=1.31 \pm 0.51$ ) cultivated semi-intensively, in relation to the present study. Despite this, the animals evaluated were smaller $(13.1 \pm 1.4 \mathrm{~cm}$ and $28.1 \pm 6.5 \mathrm{~g})$, reinforcing the proportional growth of the liver in relation to the body, in younger phases, as demonstrated in the present study. These small and possible differences within the same species may come from different food and environmental conditions between confined and wildlife animals (Gomiero and Braga, 2003).

This fact was confirmed by the color difference between the livers of smaller, young animals with greater energy reserves, and of larger animals, with a darker color due to the lower energy reserves, which can also be attributed to the present study (Saturnino, 2016). Under HE staining, cells with scarce cytoplasm, marked by an image of transparency, show possible cytoplasm filling with lipids and glycogen, this organ being reported in the literature as an important energy reservoir (Takashima and Hibiya, 1995).

In addition, the determination of HRS values is of great importance for understanding the disorders that may occur during morbid processes. A low rate of HRS may be related to the use of energy reserves, necessary for the maintenance of homeostasis (Tavares-Dias et al., 2018). Data of this nature make it possible to generate information about characteristics about species in their cultivation habitat, and their relationships, in the search for understanding possible imbalances, as well as in pathological processes (Tavares-Dias et al., 2000; Benacon et al., 2015).

With regard to histological characterization, the present study corroborates general descriptions for teleosts (Bruslé and Anadon, 1996; Costa et al., 2012). In this context, other general studies on the histology of the liver in teleosts make a similar description in the observation of the pancreas with the hepatic tissue (Morrison, 2007). Rodrigues et al. (2017) also report similar observations in a surubim hybrid, but stressed that there are still variations, as in $C$. macropomum, with diffuse distribution of the pancreas, not involving vessels, only (Costa et al., 2012).

Melanomacrophage centers are observed as distinct groups of pigmented cells, usually found associated with the reticuloendothelial matrix that supports hematopoietic tissues, including peri-portal areas of the liver (Macchi et al., 1992). Besides that, the morphological aspect of melanomacrophage centers can vary between species, organs and even between physiological conditions within the same species, such as age, starvation, tissue damage, ferric and hemoglobin metabolism, pathological and inflammatory conditions, and immunological processes, as well as environmental changes (Agius and Roberts, 2003).

Flores-Lopes and Malabarba (2007) evaluated 45 viscera of Astyanax jacuhiensis Cope, 1894 where MMC's were observed in only two individuals, demonstrating that in the same species, there may be variation in the formation of these cells, according to the immunological condition of each individual. In this context, it is necessary to study other organs related to the immune system to ascertain the presence of MMC's in this species, and the role that each viscus has as a defense organ. However, it is worth clarifying that a smaller number of these structures may be indicative of low immune challenges, as well as good sanitary conditions on the property (Steinel and Bolnick, 2017), corroborating with the present study that presented an ideal condition factor. In this context, new studies on B. amazonicus may help to understand the observation of these cells only in animals with greater growth.

The greater representativeness of hepatocytes in PI, over the others, can be attributed to the greater amount of energy reserves in the cytoplasm of these cells in this phase of body growth, as reported in A. gigas (Saturnino, 2016).

The proportion of pancreatic tissue increasing along with body weight demonstrated its growing organic role for this species. The development of pancreatic tissue around the vessels occurs during ontogenesis, and this tissue can remain extrahepatic or penetrate the liver (Bruslé and Anadon, 1996; Bombonato et al., 2007), as observed in the present study.

In their study with a surubim hybrid, Rodrigues et al. (2017) reports that the bile ducts were surrounded by a thin layer of connective tissue and exhibited variable diameters, being diffusively in the parenchyma. The histoarchitecture of the liver was similar in all the categories evaluated, without altering the percentage of hepatocytes, vessels, sinusoids, pancreatic tissue and connective tissue. This fact was not observed during the growth of B. amazonicus, where category GII showed alteration in the volumetric density of its constituents. In A. gigas variability is reported in the proportion of sinusoidal space (6.59\% to $25.50 \%$ ), and blood vessels (1.17\% to $4.32 \%$ ) among the categories evaluated (Saturnino, 2016), being greater than that found in this study, demonstrating the variability between species, and the importance of continuous studies of this nature.

The scarcity of studies related to hepatic volumetric density makes it difficult to carry out comparative studies with this species under different growing conditions, as well as with other species. Despite this, the present study offers information on $B$. amazonicus in a semi-intensive cultivation system and its liver development, encouraging the need for further research on the role of the liver and other viscera in this and other species, especially regarding cultivation systems, aiming to improve health and productivity.

In conclusion, B. amazonicus has characteristics similar to other fish species, in addition to specificities about its hepatic morphology. Therefore, studies of this nature demonstrate the importance and create demands for new research, for continuous characterization of the species, comparison with others, and evaluation under different cultivation conditions. 


\section{Acknowledgements}

The authors thank of Veterinary Parasitology and Pathology Laboratory of Federal University of Jatai for support received for the development of the project.

\section{References}

AGIUS, C. and ROBERTS, R.J., 2003. Melanomacrophage centers and their role in fish pathology. Journal of Fish Diseases, vol. 26, no. 9, pp. 499-509. http://dx.doi.org/10.1046/j.13652761.2003.00485.x. PMid:14575368.

ANATER, A., ARAÚJO, C.M.T.D., ROCHA, D.C.C., OSTRENSKY, A., FILHO, J.R.E., RIBEIRO, D.R. and PIMPÃO, C.T., 2020. Evaluation of growth performance, hematological, biochemical and histopathological parameters of Rhamdia quelen fed with a feed artificially contaminated with aflatoxin B1. Aquaculture Reports, vol. 17, pp. e100326. http://dx.doi.org/10.1016/j.aqrep.2020.100326.

BARROS, I.B.A., VILLACORTA-CORREA, M.A. and CARVALHO, T.B., 2019. Stocking density and water temperature as modulators of aggressiveness, survival and zootechnical performance in matrinxã larvae, Brycon amazonicus. Aquaculture (Amsterdam, Netherlands), vol. 502, pp. 378-383. http://dx.doi.org/10.1016/j. aquaculture.2018.12.070.

BEDOYA-SERNA, C.M., MICHELIN, E.C., MASSOCCO, M.M., CARRION, L.C.S., GODOY, S.H.S., LIMA, C.G., CECCARELLI, P.S., YASUI, G.S., ROTTINGHAUS, G.E., SOUSA, R.L.M. and FERNANDES, A.M.2018, Effects of dietary aflatoxin B1 on accumulation and performance in matrinxã fish (Brycon cephalus). PLoS One, vol. 13, no. 8, pp. e0201812. http://dx.doi.org/10.1371/journal.pone.0201812. PMid:30089140.

BENACON, M.D.S., DOS SANTOS, S.M., ARAÚJO, R.L., PANTOJA-LIMA, J., ARIDE, P.H.R. and DE OLIVEIRA, A.T., 2015. Body condition indexes of Brycon amazonicus Matrinxã of the Juruá River, Amazonas. Colombian Journal Animal Science, vol. 7, no. 1, pp. 44-49. http://dx.doi.org/10.24188/recia.v7.n1.2015.421.

BOMBONATO, M.T.S., ROCHEL, S.S., VICENTINI, C.A. and VICENTINI, I.B.F., 2007. Morphological study of the liver tissue of Leporinus macrocephalus. Acta Scientiarum. Biological Sciences, vol. 29, no. 1, pp. 81-85. http://dx.doi.org/10.4025/actascibiolsci.v29i1.157.

BRAGA, F.M.S., 1986. Estudo entre fator de condição e relação peso/ comprimento para alguns peixes marinhos. Revista Brasileira de Biologia, vol. 46, no. 2, pp. 339-346.

BRUSLÉ, J. and ANADON, G.G., 1996. The structure and function of fish liver. In: J.S.D. MUNSHI and H.M. DUTTA. Fish morphology. North-Holland: Science Publishers, pp. 77-93.

COSTA, G.D.M., ORTIS, R.C., LIMA, M.G.D., CASALS, J.B., LIMA, A.R.D. and KFOURY JUNIOR, J.R., 2012. Morphological structure of the tambaqui liver Colossoma macropomum (Cuvier, 1818). Brazilian Veterinary Research, vol. 32, no. 9, pp. 947-950. http://dx.doi. org/10.1590/S0100-736X2012000900022.

FAUGHT, E. and VIJAYAN, M.M., 2016. Mechanisms of cortisol action in fish hepatocytes. Comparative Biochemistry and Physiology. Part B, Biochemistry \& Molecular Biology, vol. 199, pp. 136-145. http://dx.doi.org/10.1016/j.cbpb.2016.06.012. PMid:27445122.

FERGUSON, H.W., 1989. Systemic pathology of fish, a text and atlas of comparative tissue responses in diseases of teleosts. Ames: Iowa State University Press, 278 p.

FISHER, J.P. and MYERS, M.S., 2000. Fish necropsy. In: G. OSTRANDER. The laboratory fish. Cambridge: Academic Press, pp. 543-556. http://dx.doi.org/10.1016/B978-012529650-2/50041-X.
FLORES-LOPES, F. and MALABARBA, L.R., 2007. Alterações histopatológicas observadas no fígado do lambari Astyanax jacuhiensis (cope, 1894) (Teleostei, Characidae) sob influência de efluentes petroquímicos. Biociencias, vol. 15, no. 2, pp. 166-172.

FLYNN, M.N., LOURO, M.P., SILVA, L.C.M. and ROSSI, M.V., 2011. Water quality and biodiversity indicators of the Jaguari-Mirim River in the stretch between the small hydroelectric plants of São José and São Joaquim, São João da Boa Vista, São Paulo. RevInter Intertox Magazine on Toxicology, Environmental Risk and Society, vol. 4, pp. 51-64. http://dx.doi.org/10.22280/ revintervol4ed2.76.

FOOD AND AGRICULTURE ORGANIZATION OF THE UNITED NATIONS - FAO, 2017 [viewed 22 February 2020]. The future of food and agriculture - Trends and challenges [online]. Rome: FAO, pp. 127. Available from: http://www.fao.org/3/a-i6583e.pdf

FOOD AND AGRICULTURE ORGANIZATION OF THE UNITED NATIONS - FAO, 2020 [viewed 22 February 2020]. The State of World Fisheries and Aquaculture 2020. Sustainability in action. Rome: FAO, pp. 244. https://doi.org/10.4060/ca9229en.

GENTEN, F., TERWINGHE, E. and DANGUY, A., 2009. Atlas of fish histology. Enfield: CRC Press, 219 p.

GOMIERO, L.M. and BRAGA, F.M.S., 2003. Relação peso-comprimento e fator de condição para Cichla cf. ocellaris e Cichla monoculus (Perciformes, Cichlidae) no reservatório de Volta Grande, rio Grande-MG/SP. Acta Scientiarum. Biological Sciences, vol. 25, no. 1, pp. 79-86. http://dx.doi.org/10.4025/actascibiolsci.v25i1.2119.

HONCZARYK, A. and INOUE, L.A.K.A., 2009. Produção comercial de alevinos de matrinxã na Amazônia Ocidental [online]. Manaus: Embrapa Amazônia Ocidental, Circular Técnica, no. 33. Available from: https://www.infoteca.cnptia.embrapa.br/bitstream/ doc/931452/1/CircTec332009.pdf

INSTITUTO BRASILEIRO DE GEOGRAFIA E ESTATÍSTICA - IBGE, 2020 [viewed 22 February 2020]. Dados da aquicultura no Brasil com ano base de 2019 [online]. Rio de Janeiro: IBGE. Available from: https://cidades.ibge.gov.br/brasil/pesquisa/18/16459

LE CREN, E.D., 1951. The length-weight relationship and seasonal cycle in gonad weight and condition in the perch (Perca fluviatilis). Journal of Animal Ecology, vol. 20, no. 2, pp. 201-219. http://dx.doi.org/10.2307/1540.

MACCHI, G.J., ROMANO, L.A. and CHRISTIANSEN, H.E., 1992. Melanomacrophage centres in white mouth croaker Micropogonias furneri, as biological indicators of environmental changes. Journal of Fish Biology, vol. 40, no. 6, pp. 971-973. http://dx.doi. org/10.1111/j.1095-8649.1992.tb02643.x.

MAHFOUZ, M.E. and SHERIF, A.H.A., 2015. A multiparameter investigation into adverse effects of aflatoxin on Oreochromis niloticus health status. Journal of Basic E Applied Zoology, vol. 71, pp. 48-59. http://dx.doi.org/10.1016/j.jobaz.2015.04.008.

MORRISON, J., 2007. Normal histology. In: S. MUMFORD, J. HEIDEL, C. SMITH, J. MORRISON, B. MACCONNELL and V. BLAZER. Fish hitology and histopathology manual. USA: United States Fish and Wildlife Service - National Conservation Training Center. Available from: https://nctc.fws.gov/resources/course-resources/ fish-histology/Fish_Histology_Manual_v4.pdf

NAVARRO, R.D., DA SILVA, R.F., RIBEIRO FILHO, O.P., CALADO, L.L., REZENDE, F.P., SILVA, C.S. and SANTOS, L.C., 2006. Comparação morfométrica e índices somáticos de machos e fêmeas do lambari prata (Astayanax scabripinnis Jerenyns, 1842) em diferente sistema de cultivo. Zootecnia Tropical, vol. 24, no. 2, pp. 165-176.

REGO, A.C.L., PINESE, O.P., MAGALHÃES, P.A. and PINESE, J.F., 2008. Relação peso-comprimento para Prochilodus lineatus (Valenciennes, 1836) e Leporinus friderici (Bloch, 1794) 
(Characiformes) no reservatório de Nova Ponte -EPDA de Galheiro, Rio Araguari, MG. Revista Brasileira de Zoociências, vol. 10, pp. 13-21.

RODRIGUES, R.A., SATURNINO, K.C. and FERNANDES, C.E., 2017. Liver histology and histomorphometry in hybrid sorubim (Pseudoplatystoma reticulatum $\mathrm{x}$ Pseudoplatystoma corruscans) reared on intensive fish farming. Aquaculture Research, vol. 48, no. 9, pp. 5083-5093. http://dx.doi.org/10.1111/are.13325.

SANTOS, G., FERREIRA, E. and ZUANON, J., 2006. Peixes comerciais de Manaus. Manaus: IBAMA/AM, Pro Várzea, 144 p.

SATURNINO, K.C., 2016. Biometria e histomorfologia de figado, baço e rim de Arapaima gigas em piscicultura semi-intensiva. Campo Grande: Universidade Federal do Mato Grosso do Sul, 86 p. Tese de Doutorado em Ciência Animal.

STEINEL, N.C. and BOLNICK, D.I., 2017. Melanomacrophage centers as a histological indicator of immune function in fish and other poikilotherms. Frontiers in Immunology, vol. 8, pp. 827. http://dx.doi.org/10.3389/fimmu.2017.00827. PMid:28769932.

SUNDBERG, M.D., 1992. An introduction to stereological analysis: morphometric techniques for beginning biologists. In: C.A. GOLDMAN, S.E. ANDREWS, P.L. HAUTA and R. KETCHUM. Tested studies for laboratory teaching. Proceedings of the $6^{\text {th }}$ Workshop/ Conference of the Association for Biology Laboratory Education (ABLE). Iowa: Kendall/Hunt Publishing Company, pp. 51-57.

TAKASHIMA, F. and HIBIYA, T., 1995. An atlas of fish histology normal and pathological features. Kodansha: Gustav Fischer Verlag, 147 p.

TAVARES-DIAS, M., MARCON, J.L., LEMOS, J.R., FIM, J.D., AFFONSO, E.G. and ONO, E.A., 2018 [viewed 20 February 2020]. Body condition indexes in juveniles of Brycon amazonicus (SPIX \& AGASSIZ, 1829) and Colossomoma macropomum (CUVIER, 1818) in the Amazon. Boletim do Instituto de Pesca [online], vol. 34, pp. 197-204. Available from: https://www.pesca.sp.gov.br/ boletim/index.php/bip/article/view/786

TAVARES-DIAS, M., MARTINS, M.L. and MORAES, F.R., 2000. Relação hepatosomática e esplenosomática em peixes teleósteos de cultivo intensivo. Revista Brasileira de Zoologia, vol. 17, no. 1, pp. 273-281. http://dx.doi.org/10.1590/S0101-81752000000100024.

USHIZIMA, T.T., TAVARES, A.L.A., PEREIRA, A.A., SILVA, D.A. and MARTVI, P.H.C., 2016 [viewed 20 October 2020]. Manual de boas práticas de produção em piscicultura (Manual Técnico) [online]. Available from: http://www.nutrizon.com.br/ 